\title{
Sustainability of EU Fiscal Policies: a Panel Test
}

\author{
Peter Claeys \\ European University Institute, Universitat de Barcelona and SHERPPA
}

\begin{abstract}
The fiscal policy rule implicit in the Stability and Growth Pact, has been rationalised as a way to ensure that national fiscal policies remain sustainable within the EU, thereby endorsing the independence of the ECB. We empirically examine the sustainability of European fiscal policies over the period 1970-2001. The intertemporal government budget constraint provides a test based on the cointegration relation between government revenues, expenditures and interest payments. Sustainability is analysed at both the national level and for a European panel. Results show that European fiscal policy has been sustainable overall, yet national experiences differ considerably.
\end{abstract}

-JEL Classification: E61, E63, H63

- Keywords: Fiscal policy, Debt sustainability, Panel unit root test, Panel cointegration test, EMU

\section{Introduction}

The consolidation of public finances has somehow slid back on the priority list of European economic policy since the start of EMU. Debt ratios have stabilised if not, started to rise again - in recent years (see Fig. 1). The dilution of the deficit rule in the Stability and Growth Pact is just one indicator of the fatigue in carrying on fiscal consolidation. This evolution should not come as a surprise now that national governments have secured entry into EMU. Even if the main legacy of the

\footnotetext{
*Corresponding address: Peter Claeys, Department of Economics, European University Institute, Via della Piazzuola, 43, I-50133 Firenze, Italy. Phone: +0034 93403588, Fax: +0034 934037242, E-mail: Peter.Claeys@eui.eu.

@2007-Center for International Economics, Sejong Institution, All Rights Reserved.
} 
Fig. 1a. General government gross public debt (\% of GDP)

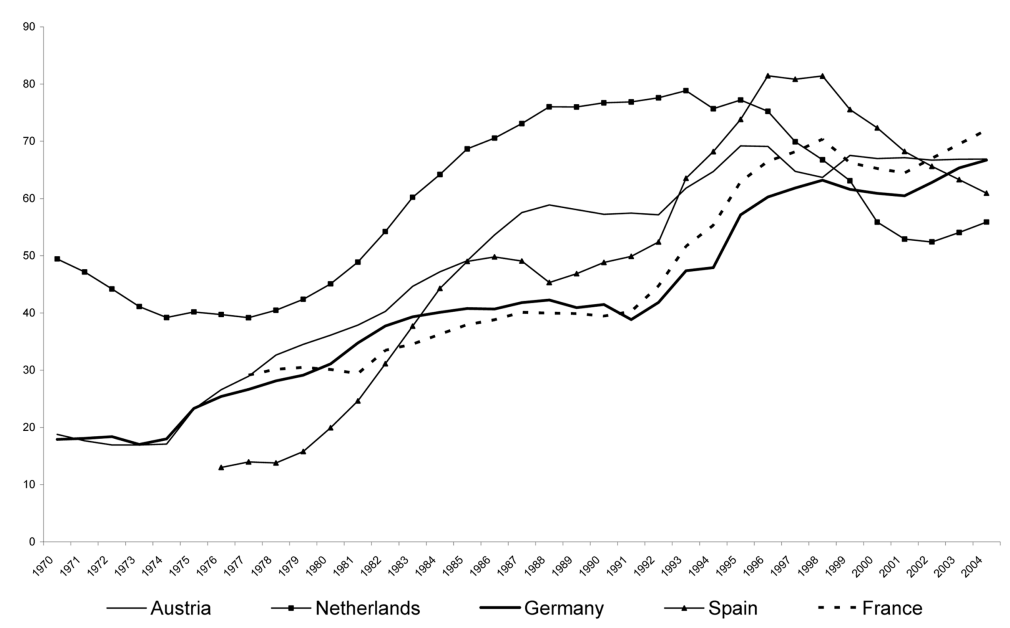

Fig. 1b. General government gross public debt (\% of GDP)

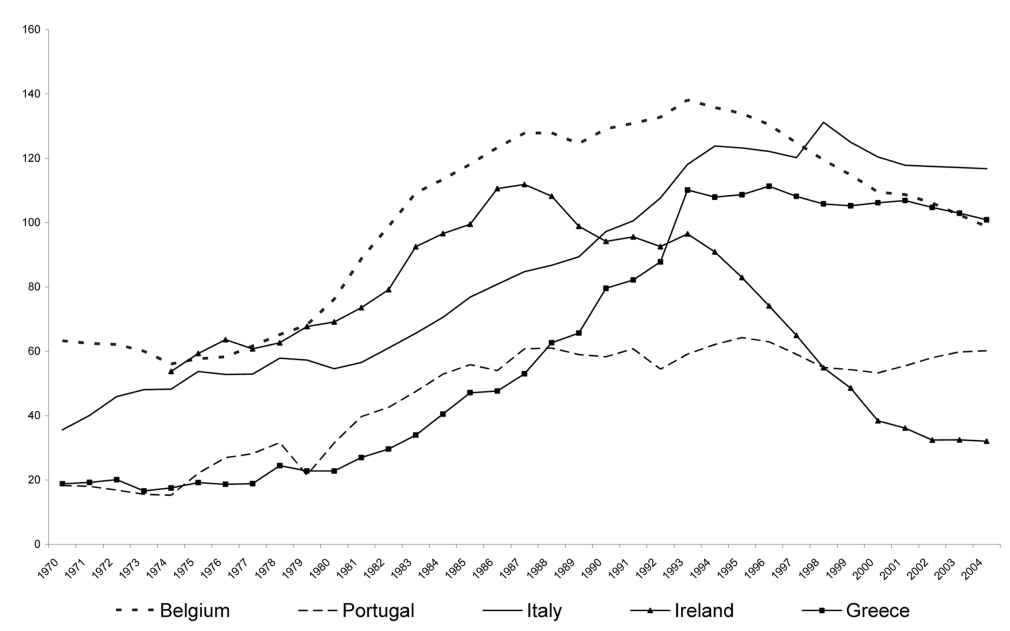

Pact is probably that of having increased public awareness of fiscal sustainability, the numerical targets of the Treaty of Maastricht and the provisions of the Pact do not adequately act as a 'stick' to force optimal policies that are based upon the use of automatic stabilisers around sustainable fiscal positions. Another interpretation, however, is that governments are fiscally lax as budget constraints are weaker within monetary union. Basically, the disciplinary effect of higher interest rates does not bite national fiscal policy as much when interest rates are set centrally. This distortion leads to excessive debt accumulation and higher interest rates across 
Fig. 1c. General government gross public debt (\% of GDP)

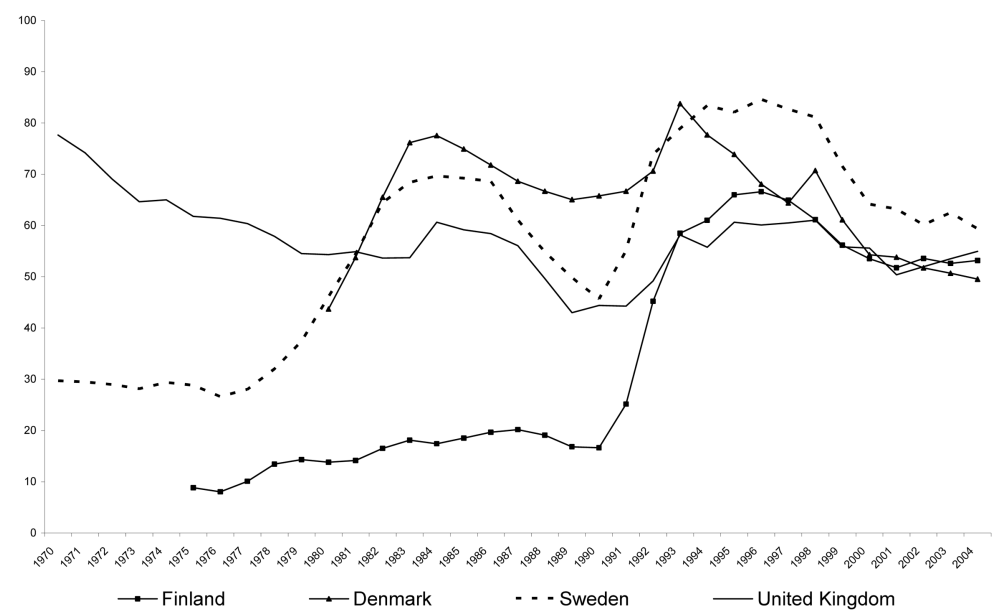

the monetary union (Beetsma and Bovenberg, 1999). Keeping in order the national fiscal houses is not a sufficient condition to eliminate these effects. Deficit rules address this free riding problem only indirectly. It is only a negative coordination mechanism for debt consolidation. Instead, it is the no-bailout clause - enshrined in Articles 101 and 103 of the Treaty of Nice - that is crucial in disciplining national fiscal policies. Essentially, the clause prohibits overdraft facilities from the ECB or the assumption of national commitments by other Member States, and thus separates responsibilities between the various national fiscal policies. The revision of the Pact has severely dented the reputation of intergovernmental renegotiations. In addition, the political and economic cohesion of monetary union may require fiscal support across regions. At present, the bailout scenario seems remote, but cannot be excluded as an option. There is indeed some evidence that market discipline does not function in the European bond markets. EMU Member States pay markedly lower default premia on outstanding debt (see Bernoth et al., 2004). Paradoxally, the fiscal relations between EU Member States may have become more closely tied across borders since the breakdown of the Pact.

Consequently, tests of sustainability on each national fiscal policy turn out to be less insightful. The overall sustainability of public finances in monetary union should be tested instead. We propose a simple test for sustainability that is based on excluding Ponzi games as a viable option of government finance. By ruling out $\mathrm{ad}$ infinitum borrowing to cover interest payments on outstanding debt, the government budget constraint implies a cointegration relation between real government 
expenditures, revenues and net interest payments. Analysing this relationship for each European government's fiscal policy is awkward because of small sample problems. An examination of the overall fiscal position of European governments with panel techniques precisely allow us to overcome this problem. A panel test for aggregate sustainability is also consistent with the independent setting of national fiscal policies.

In section 2, we present a specification of the intertemporal government budget constraint in order to derive some alternative testing strategies of fiscal sustainability, and particularly the use of cointegration. The sustainability hypothesis is then tested in section 3, first at the national level, then for the European panel. We check whether the assumptions underlying our testing procedure hold, and accordingly discuss some extensions of the panel test. Finally, section 4 concludes and offers suggestions for future research.

\section{Alternative Strategies of Testing Sustainability}

We start the discussion from the flow government budget constraint (FGBC henceforth). The period-by-period budget constraint simply defines total debt $D_{t}$ as the accumulation due to interest payments on past fiscal imbalances and primary net lending $S_{t}$, including seigniorage revenues received from the central bank:

$$
D_{t} \equiv\left(1+r_{t}\right) D_{t-1}+S_{t}
$$

Under the assumption that real interest rates $r_{t}$ are positive (for all $t$ ), this can be presented as an unstable non-homogeneous difference equation. Solving the identity (1) forward yields the intertemporal government budget constraint (IGBC henceforth):

$$
D_{t}=\lim _{N \rightarrow \infty} E_{t}\left[\prod_{j=1}^{N}\left(\frac{D_{1+N}}{1+r_{1+j}}\right)\right]+\sum_{k=0}^{\infty} E_{t}\left[\prod_{j=1}^{k}\left(\frac{S_{1+k}}{1+r_{1+j}}\right)\right] .
$$

The government complies with this constraint when the sum of the present discounted value of expected future primary surpluses just suffices to pay off current debt. In other words, the sustainability condition is met when the public sector does not hold public assets or need to alienate liabilities with any positive probability. Testing the sustainability of fiscal policy thus reduces to testing the hypothesis that the transversality condition holds: 


$$
\lim _{N \rightarrow \infty} E_{t}\left[\prod_{j=1}^{N}\left(\frac{D_{1+N}}{1+r_{1+j}}\right)\right]=0 .
$$

In a stochastic environment, observable fiscal indicators can render tests of the transversality condition highly misleading. To illustrate this, suppose interest rates on government bonds were smaller than the rate of economic growth. Prolonged periods with primary deficits do not indicate an unsustainable fiscal position per se. In such a dynamically inefficient economy, the IGBC is in fact irrelevant as debt can be rolled over indefinitely. But if the interest rate were to surpass the GDP growth rate with some positive probability, even zero primary surpluses would become unsustainable. One needs to look for an adequate test of the IGBC that is not only robust to time-variant interest rates but also to different debt management policies and the implications of uncertainty and risk aversion.

One such test is suggested by Trehan and Walsh (1991). They prove that a stationary quasi-difference of debt is sufficient for the transversality condition to hold, if and only if debt and the primary surplus are cointegrated. Artis and Marcellino (1998) generally find such cointegration relations for all European countries. However, Bravo and Silvestre (2002), among others find no-cointegration of expenditure and revenue ratios in several EU countries. A stationary linear combination of debt and primary surplus is rejected by Trehan and Walsh (1991) for the US. Quintos (1995) and Ahmed and Rogers (1995) show that cointegration between non-stationary government expenditures $G_{t}$, revenues $T_{t}$ and net interest payments $r_{t} D_{t}-1$ is a necessary condition for the present value constraint to be satisfied if these series are at most integrated of order one and some weak economic assumptions hold. The latter require: (a) agents to hold rational expectations; (b) utility of consumption to follow a random walk; and (c) the covariance of marginal rates of substitution in consumption with fiscal variables to be time-invariant. ${ }^{1}$ As a consequence, total net lending of the government $\tilde{S}_{t}$ is stationary:

$$
\tilde{S}_{t}=G_{t}-T_{t}+r_{t} D_{t-1}
$$

Conversely, cointegration is also a sufficient condition under the auxiliary

\footnotetext{
${ }^{1}$ Hakkio and Rush (1991) derive a test for cointegration under similar assumptions, but require in addition that real interest rates are stationary. On quarterly US data, they reject cointegration between spending and revenues. Haug (1990) examines a short quarterly sample from 1960 to 1987, and still concludes the IGBC holds. Quintos (1995) finds evidence for cointegration and weak sustainability.
} 
assumptions (a)-(c) and for a very general class of time series processes for debt (Ahmed and Rogers, 1995). It is sufficient that debt is at most integrated of order one. Thus, the limit term being zero implies the sum of current and expected discounted future government expenditures and revenues are set such as to equal the amount needed to repay principal and interest on $\mathrm{debt}^{2}$.

With an unspecified cointegrating vector, only weak sustainability can be said to hold. This implies the undiscounted debt process is exploding at a rate less than the economy's growth rate. In contrast, strong sustainability implies that the undiscounted public debt is finite in the long run. This occurs if the total government net lending series is stationary, or when government revenues, spending and interest payments are cointegrated, with cointegrating vector equal to

$$
\beta=[1,-1,1]
$$

Corsetti and Roubini (1991), Artis and Marcellino (1998), Bravo and Silvestre (2002) or Arghyrou and Luintel (2005), for example.

The concept underlying cointegration is similar to the stabilising reaction of the primary surplus to public debt. In this 'fiscal rule', policy adjusts to deviations from the present value constraint in a similar way as primary surpluses react to shocks to the path of debt (Bohn, 1998).

How realistic is it to test the implication of the IGBC that the present discounted value of primary surpluses equals current debt? After all, the discussion is limited to a pure time series analysis of sustainability, and there may simply not be enough memory in the historical DGP of fiscal data to infer upon concepts that hold at infinite horizons (Hansen et al., 1991; Canzoneri et al., 2001). Analyses that involve policy simulations and fiscal forecasts are not considered, even if they may be more relevant from a policy point of perspective. Solvency is essentially a forward-looking concept where policy shifts may perturb any definite conclusion on the basis of past policy conduct. While this is an inference problem that plagues any empirical analysis, the problem of small samples also induces some econometric problems, since unit root and cointegration tests have well known small sample bias. This has been avoided by using century-long samples of fiscal policy in the United States (Ahmed and Rogers, 1995; Bohn, 2005), the United Kingdom (Ahmed and Rogers,

${ }^{2}$ Bohn (1998) contends that cointegration is a necessary condition for sustainability. Such conditions only apply if the fiscal variables follow an I(1) process but this restriction need to be justified on economic grounds. 
1995) or Portugal (Marinheiro, 2006). But for the majority of European countries, yearly fiscal data are only available over limited time spans. This partly explains the rather inconclusive results of many of these studies: it is easy to cite a variety of studies for the same country that find conflicting results ${ }^{3}$. Evidence in Afonso (2005) based on cointegration tests illustrates the smal sample problem for a comprehensive set of countries ${ }^{4}$. The recent literature on cointegration in macropanels is a first step towards a joint examination of sustainability of European fiscal policies.

\section{An Empirical Test of Sustainability of EU Fiscal Policies}

\section{A. Dataset}

We construct annual data on real government expenditures $\left(G_{t}\right)$, real government revenues $\left(T_{t}\right)$ and real net interest payments $\left(r_{t} D_{t-1}\right)$ for 14 European countries, all of which are subject to the Stability or Convergence Programmes of the European Commission. The dataset comprehends all all the EU-countries, with the exception of Luxembourg and the New Member States. The data source is the OECD Economic Outlook and spans the period 1970-2001 or a subsample thereof. All current and investment outlays are included in government expenditures. Net interest payments are not calculated as in the theoretical cointegration vector (4), but we experiment with two different measures instead. The first one contains net interest payments on outstanding government debt. The second one takes into account all government capital transactions. This seems a more realistic approximation of smooth debt management policies. All data are measured in undiscounted real levels. This follows immediately from the necessary conditions for the existence of a cointegration relationship between $G_{t}, T_{t}$ and $r_{t} D_{t-1}$.

In the initial empirical analysis, we merely replicate existing evidence on the sustainability of fiscal policy in single European countries with cointegration tests on the IGBC, and unit root tests on the primary surplus and debt to GDP ratios. These results serve as input for the panel unit root and panel cointegration tests on sustainability. As panel tests are only valid under the stringent assumptions of

${ }^{3}$ Corsetti and Roubini (1991), Artis and Marcellino (1998), Bravo and Silvestre (2002) or Arghyrou and Luintel (2005), for example.

${ }^{4}$ A fonso (2005) gives an excellent detailed overview of the various approaches for testing sustainability, and also provides a comprehensive list of empirical studies. 
Table 1. Unit root tests

\begin{tabular}{|c|c|c|c|c|c|c|c|c|c|}
\hline \multirow{3}{*}{$\begin{array}{c}\text { Test }^{(\mathrm{c})} \\
\text { Country }\end{array}$} & \multicolumn{3}{|c|}{ Real expenditure } & \multicolumn{3}{|c|}{ Real revenues } & \multicolumn{3}{|c|}{$\begin{array}{l}\text { Real net interest } \\
\text { payments }\end{array}$} \\
\hline & \multirow[t]{2}{*}{$\mathrm{ADF}^{(\mathrm{a})}$} & \multicolumn{2}{|c|}{$\mathrm{KPSS}^{(\mathrm{b})}$} & \multirow[t]{2}{*}{$\mathrm{ADF}^{(\mathrm{a})}$} & \multicolumn{2}{|c|}{$\mathrm{KPSS}^{(\mathrm{b})}$} & \multirow[t]{2}{*}{$\mathrm{ADF}^{(\mathrm{a})}$} & \multicolumn{2}{|c|}{$\mathrm{KPSS}^{(\mathrm{b})}$} \\
\hline & & $\mu$ & $\tau$ & & $\mu$ & $\tau$ & & $\mu$ & $\tau$ \\
\hline Austria & $*$ & $*$ & $*$ & $*$ & $*$ & $*_{\mathrm{S}}$ & $*$ & 0 & $*$ \\
\hline Belgium & $*$ & $*_{\mathrm{S}}$ & $*_{\mathrm{S}}$ & $*$ & $*$ & $*_{\mathrm{S}}$ & 0 & 0 & 0 \\
\hline Denmark & $*$ & $*$ & $*$ & * & $*$ & $*_{\mathrm{S}}$ & 0 & 0 & 0 \\
\hline Germany & * & $*$ & $*$ & * & $*$ & $*_{\mathrm{S}}$ & 0 & $*$ & 0 \\
\hline Spain & * & $*$ & $*$ & * & $*$ & $*_{\mathrm{S}}$ & 0 & $*$ & $*_{\mathrm{S}}$ \\
\hline Finland & $*$ & $*_{\mathrm{S}}$ & $*_{\mathrm{s}}$ & $*$ & $*$ & $*$ & $*_{\mathrm{S}}$ & $*$ & $*_{\mathrm{s}}$ \\
\hline France & * & $*$ & $*_{\mathrm{S}}$ & * & $*$ & * & 0 & $*$ & 0 \\
\hline Great Britain & $*$ & $*$ & $*_{\mathrm{S}}$ & $*$ & $*$ & $*$ & 0 & 0 & 0 \\
\hline Greece & $*$ & $*$ & $*_{\mathrm{s}}$ & $*_{\mathrm{s}}$ & * & $*_{\mathrm{s}}$ & * & 0 & $*$ \\
\hline Ireland & $*_{\mathrm{S}}$ & $*$ & $*$ & $*$ & $*$ & $*_{\mathrm{S}}$ & 0 & $*$ & 0 \\
\hline Italy & $*_{\mathrm{S}}$ & $*$ & $*_{\mathrm{S}}$ & * & $*$ & $*_{\mathrm{S}}$ & 0 & 0 & $*$ \\
\hline Netherlands & $*$ & $*$ & $*_{\mathrm{s}}$ & $*$ & $*$ & * & 0 & $*$ & 0 \\
\hline Portugal & $*$ & $*$ & $*_{\mathrm{S}}$ & $*$ & $*$ & $*_{\mathrm{S}}$ & 0 & $*$ & $*$ \\
\hline Sweden & $*_{\mathrm{S}}$ & $*$ & $*_{\mathrm{s}}$ & $*$ & $*$ & $*$ & 0 & 0 & 0 \\
\hline
\end{tabular}

Note: (a) ADF-test allowing for trend; (b) KPSS test: $\mu$ for level stationarity, $\tau$ for trend stationarity; (c) a * indicates the variables is $\mathrm{I}(1)$ at $5 \%$, *s indicates a stochastic trend at $5 \%$, ' 0 ' means the series is stationary.

Table 2. Unit root test on total net lending and public debt ratio

\begin{tabular}{l|ccc|ccc}
\hline \multirow{2}{*}{\multicolumn{1}{c}{ Test ${ }^{(\mathrm{c})}$}} & \multicolumn{2}{|c|}{ Total net lending ratio } & \multicolumn{3}{c}{ Gross debt ratio } \\
\cline { 2 - 7 } \multicolumn{1}{c}{ Country } & $\mathrm{ADF}^{(\mathrm{a})}$ & \multicolumn{2}{c|}{$\mathrm{KPSS}^{(\mathrm{b})}$} & $\mathrm{ADF}^{(\mathrm{a})}$ & \multicolumn{2}{c}{$\mathrm{KPSS}^{(\mathrm{b})}$} \\
Austria & $*$ & $*$ & $*_{\mathrm{s}}$ & $*$ & $*$ & $*$ \\
Belgium & $*$ & $*$ & $*_{\mathrm{s}}$ & $*$ & $*$ & $*$ \\
Denmark & 0 & 0 & 0 & $*$ & 0 & $*$ \\
Germany & 0 & $*$ & 0 & $*$ & $*$ & 0 \\
Spain & $*$ & $*$ & $*$ & $*$ & $*$ & 0 \\
Finland & 0 & 0 & 0 & $*$ & $*$ & 0 \\
France & 0 & $*$ & 0 & $*$ & $*$ & 0 \\
Great Britain & 0 & 0 & 0 & $*$ & $*$ & $*$ \\
Greece & $*$ & $*$ & $* \mathrm{~s}$ & $*$ & $*$ & $*$ \\
Ireland & $*$ & $*$ & $*$ & $*$ & 0 & $*$ \\
Italy & $*$ & $*$ & $*$ & $*$ & $*$ & 0 \\
Netherlands & 0 & 0 & $* \mathrm{~s}$ & $*$ & $*$ & $*$ \\
Portugal & $* / 0$ & $*$ & $*$ & $*$ & $*$ & $*$ \\
Sweden & 0 & 0 & 0 & $*$ & $*$ & 0 \\
\hline
\end{tabular}

Note: (a) ADF-test allowing for trend; (b) KPSS test: $\mu$ for level stationarity, $\tau$ for trend stationarity; (c) a $*$ indicates the variables is $\mathrm{I}(1)$ at $5 \%$, * indicates a stochastic trend at $5 \%$. 
identical cointegrating rank and the absence of cross-sectional dependence or cointegration, we briefly test these hypotheses.

\section{B. Testing Sustainability of National Fiscal Policy}

In order to initiate the cointegration analysis, we need to establish the order of integration of the different series. We perform ADF and KPSS-tests for level and trend stationarity for the basic series: government expenditures, revenues and net interest payments. Results are displayed in Table 1. While we can never reject a unit root for expenditures or revenues, net interest payments seem to be stationary in most European countries. In Austria, Spain, Finland, Greece and Portugal, however, net interest payments evolve smoothly along a trend. For the other countries, the Treasury seems to smooth debt payments over time.

Before testing the cointegrating relationship in (4) as such, we also wanted to impose the unity cointegration coefficients from theory, as in (5). We thus calculated total net lending as in (4), but now expressed as a ratio to GDP, and performed the same unit root tests. Stationarity of total government net lending should be an

Table 3. Tests for order of cointegration

\begin{tabular}{l|cccc}
\hline \multirow{2}{*}{ Country } & \multicolumn{4}{|c}{ Cointegration relation: $G_{t}-T_{t} r_{t} D_{t-1}$} \\
\hline Austria & Lags $^{(\mathrm{a})}$ & $\operatorname{Max}^{(\mathrm{b})}$ & Trace $^{(\mathrm{b})}$ & CONCLUSION $^{(\mathrm{c})}$ \\
Belgium & 2 & 2 & 1 & 1 \\
Denmark & 2 & 2 & 2 & 2 \\
Germany & 2 & 2 & 2 & 2 \\
Spain & 2 & 2 & 2 & 2 \\
Finland & 2 & 1 & 0 & $?$ \\
France & 2 & 2 & 1 & 1 \\
Great Britain & 2 & 2 & 1 & 2 \\
Greece & 2 & 2 & 2 & 2 \\
Ireland & 2 & 1 & 0 & 2 \\
Italy & 2 & 2 & 2 & 0 \\
Netherlands & 2 & 2 & 2 & $?$ \\
Portugal & 2 & 0 & 0 & 2 \\
Sweden & 2 & 1 & 0 & 2 \\
\hline
\end{tabular}

Notes: (a) number of lags in system estimation, determined by the Akaike criterion; (b) Johansen max and trace test; (c) column entries indicate rank.

equivalent necessary condition for the IGBC to hold. As Table 2 shows, sustainability would be violated for at least half of the EU member states. These include the countries with high debt ratios as Belgium, Greece, Ireland, Italy and Portugal, but 
Table 4. Weak sustainability: implied cointegrating vector.

\begin{tabular}{l|ccr}
\hline \multicolumn{1}{c|}{ Country } & $G_{t}$ & $T_{t}$ & $r_{t} D_{t-1}$ \\
\hline Austria & 1.000 & -0.850 & -1.546 \\
Belgium & 1.000 & -0.542 & 2.532 \\
Denmark & 1.000 & -0.681 & 7.212 \\
Germany & 1.000 & -0.834 & -2.325 \\
Spain & 1.000 & -1.153 & 1.494 \\
Finland & 1.000 & -1.567 & 7.737 \\
France & 1.000 & -0.885 & 0.122 \\
Great Britain & 1.000 & -0.759 & -0.560 \\
Greece & 1.000 & -0.544 & -1.394 \\
Ireland & 1.000 & -0.613 & 1.070 \\
Italy & 1.000 & -0.634 & -6.272 \\
Netherlands & 1.000 & -0.710 & 0.802 \\
Portugal & 1.000 & -1.140 & 1.593 \\
Sweden & 1.000 & -0.836 & 3.524 \\
\hline
\end{tabular}

Note: constant not reported.

also countries with rather volatile fiscal policies as Austria and Spain. These mixed results are illustrative of the various findings in the literature. They also indicate already that cointegration may be difficult to fit to some countries ${ }^{5}$.

Explicit tests of the cointegration relation (4) are performed in a VAR specified on the three fiscal variables. A constant - that is constrained to lie in the cointegrating space - is allowed for so as to permit government debt to converge to some constant positive value. The tests for weak sustainability are the Johansen Max and Trace variants. We determine the number of lags in the system on the basis of the Akaike information criterion. The resulting cointegrating ranks are reported in Table 3. We also impose a unity cointegrating rank for all countries, and the implied cointegration vectors estimated in the corresponding VEC are reported in Table 4.

There seems to be no evidence at all for a cointegration relation in the Netherlands. Evidence is less clear-cut in the case of Spain, Greece and Portugal, however, as the Max test prefers a zero cointegrating rank. These results are consistent with the unit root test on real total net lending for the latter countries.

\footnotetext{
${ }^{5}$ Likewise, a simple unit root test on the public debt ratio only further demonstrates the inconclusiveness of sustainability tests on national fiscal policies. Now, we find the debt ratio to be stationary in Germany, Spain, Finland, France, Sweden, but also Italy.
} 
Sustainability should thus be rejected for a couple of European countries, but public finances are not problematic in most EU Member States. The implied cointegrating vectors seem overall reasonable. There is some heterogeneity around the theoretically negative unity coefficient on real government revenues. The coefficient on net interest payments does never show the expected unity coefficient - with the exception of Ireland - and in many cases even displays a negative coefficient.

The basic conclusions from both sets of results are the following: (a) there is a core group of countries where sustainability of public finances does not seem to be guaranteed. These include Spain, the Netherlands, Greece and Portugal; (b) in some other countries with notably loose fiscal stance (Austria, Belgium, Italy), non-stationarity of the implied total net lending is not always rejected; (c) the cointegration vectors implied by weak sustainability are in line with the theoretical relationship between government expenditures, revenues and net interest payments.

\section{The European Panel Test}

In order to set out the cointegration analysis, we first need to establish the order of integration of the different series. As national fiscal policies vary considerably, we definitely need to allow for substantial heterogeneity in the panel analysis. We simply model this with heterogeneous fixed effects and trends across countries. We consider two types of panel unit root tests, and compute both the tests of Levin and Lin (2002), and the ADF-test of Im, Pesaran and Shin (2003). The latter allows for heterogeneous autocorrelation under the alternative hypothesis. Results are reported in Table 5. As could be expected from the national analyses, none of the tests rejects a unit root for real government expenditures and revenues. For net interest payments, only the Levin-Lin ADF-test is unable to reject a unit root. These results should nevertheless be interpreted with caution. First, both Levin-Lin and IPS tests are derived under the assumption of balanced panels, whereas we used unbalanced ones. Second, there may be important

Table 5. Levin-Lin and Im-Pesaran-Shin panel unit root tests

\begin{tabular}{l|lcc|c}
\hline \multicolumn{1}{c|}{ Test } & \multicolumn{3}{c|}{ Levin-Lin } & IPS \\
& rho & t-rho & ADF & ADF \\
\hline Real expenditure & 0.493 & -0.428 & 0.680 & -0.044 \\
Real revenues & 2.583 & 0.698 & 1.139 & 0.730 \\
Real net interest payments & $-6.870^{* * *}$ & $-2.332^{* *}$ & -0.751 & $-1.947^{*}$ \\
\hline
\end{tabular}

Note: (a) $* * *$ indicates significance at the $1 \%$ level, $* *$ at $5 \%, *$ at $10 \%$. 
Table 6. Pedroni panel cointegration tests: test statistics from Pedroni (1999)

\begin{tabular}{l|c}
\hline \multicolumn{2}{c}{ Full panel (14 countries): sample period 1970-2001 } \\
\hline panel v-stat & $2.15^{* *}$ \\
panel rho-stat & $-2.24 * *$ \\
panel PP-stat & $-3.73^{* * *}$ \\
panel ADF-stat & -0.44 \\
group rho-stat & $-2.06^{* *}$ \\
group PP-stat & $-5.24 * * *$ \\
group ADF-stat & $-2.48^{* *}$ \\
\hline
\end{tabular}

Note: (a) $* * *$ indicates significance at the $1 \%$ level, $* *$ at $5 \%,{ }^{*}$ at $10 \%$.

Table 7. Pedroni panel cointegration tests: test statistics from Pedroni (1999)

\begin{tabular}{lc|lc}
\hline \multicolumn{4}{c}{ Countries grouped to cointegration $G_{t}-T_{t} r_{t-1} D_{t-1}$} \\
\hline \multicolumn{2}{c}{ Panel } & \multicolumn{2}{c}{ Panel } \\
(AUT, DEU, DNK, FIN, GBR, IRE, ITA, SWE) & (BEL, ESP, FRA, GRC, NLD, PRT) \\
\hline panel v-stat & 1.51 & panel v-stat & -1.06 \\
panel rho-stat & 0.32 & panel rho-stat & 0.24 \\
panel PP-stat & -0.14 & panel PP-stat & -0.62 \\
panel ADF-stat & 1.39 & panel ADF-stat & -0.72 \\
group rho-stat & 0.94 & group rho-stat & 0.13 \\
group PP-stat & -0.05 & group PP-stat & -1.36 \\
group ADF-stat & 0.96 & group ADF-stat & $-2.16^{* *}$ \\
\hline \multicolumn{5}{c}{ Countries grouped to non-stationary net lending } \\
\hline Panel & & & \\
(DEU, FIN, FRA, GBR, NLD, SWE) & (AUT, BEL, ESP, GRC, IRE, ITA, PRT) & 0.50 \\
panel v-stat & -0.40 & panel v-stat & 0.45 \\
panel rho-stat & 0.29 & panel rho-stat & -0.56 \\
panel PP-stat & -0.12 & panel PP-stat & 1.45 \\
panel ADF-stat & 0.53 & panel ADF-stat & 0.40 \\
group rho-stat & 0.89 & group rho-stat & -0.90 \\
group PP-stat & 0.25 & group PP-stat & 0.36 \\
group ADF-stat & -0.02 & group ADF-stat &
\end{tabular}

Note: (a) $* * *$ indicates significance at the $1 \%$ level, $* *$ at $5 \%, *$ at $10 \%$.

comovements across the national series. This will be examined further in section 3.4 .

We then continue to test the cointegration relation (4) for the full panel of European countries. As was evident from the national cointegration relations, there is more support for the weak version that displays substantially different coefficients (see Table 4). We therefore apply the residual-based method of Pedroni (1997) that incorporates a lot of heterogeneity through heterogeneous fixed effects, 
slope coefficients and deterministic trends across countries. Results are summarised in Table 6. In the unbalanced panel of 14 countries, the null of no cointegration can be safely rejected at a significance level of at least 5 per cent. Only the panel ADFtest statistic gives contrary evidence, but we would prefer to attach more importance to the group tests as these allow for heterogeneity in the persistence of the residuals. It thus seems that sustainability is guaranteed for the ensemble of European governments.

\section{Do the Assumptions Hold?}

All of the asymptotic properties of the panel stationarity test statistics have been derived under two rather stringent assumptions that are hard to bring about in empirical exercises (Banerjee et al., 2005).

\section{Assumption 1:is the order of cointegration identical across countries?}

As was already evident from the national tests in Table 3, the order of cointegration differs across countries. In order to check whether this had any influence on our results, we grouped the countries in two different panels. None of the panel cointegration tests (Table 7) for either the eight 'solvent' countries or the six bad ('insolvent') performers rejects the null of no cointegration, though ${ }^{6}$. While

Table 8. An analysis of bilateral international cointegration .

\begin{tabular}{|c|c|c|c|c|c|c|c|c|c|c|c|c|c|}
\hline & AUT & BEL & DEU & ESP & FIN & FRA & GBR & GRC & IRE & ITA & NLD & PRT & SWE \\
\hline$\overline{\mathrm{AUT}}$ & - & $2 / 2$ & $4 / 3$ & $3 / 2$ & $4 / 3$ & $1 / 1$ & $4 / 4$ & $3 / 3$ & $4 / 3$ & $4 / 3$ & $3 / 1$ & $2 / 2$ & $2 / 2$ \\
\hline BEL & & - & $3 / 3$ & $4 / 4$ & $4 / 3$ & $2 / 1$ & $4 / 3$ & $4 / 3$ & $3 / 3$ & $4 / 3$ & $3 / 2$ & $3 / 2$ & $3 / 2$ \\
\hline DEU & & & - & $3 / 1$ & $3 / 2$ & $3 / 3$ & $3 / 2$ & $4 / 3$ & $3 / 2$ & $3 / 3$ & $5 / 4$ & $2 / 1$ & $3 / 3$ \\
\hline ESP & & & & - & $4 / 3$ & $4 / 3$ & $3 / 3$ & $4 / 4$ & $4 / 5$ & $3 / 2$ & $3 / 2$ & $4 / 1$ & $3 / 2$ \\
\hline FIN & & & & & - & $3 / 2$ & $4 / 4$ & $4 / 3$ & $4 / 4$ & $5 / 5$ & $2 / 1$ & $3 / 2$ & $3 / 2$ \\
\hline FRA & & & & & & - & $3 / 2$ & $3 / 2$ & $5 / 5$ & $4 / 3$ & $3 / 2$ & $4 / 2$ & $4 / 3$ \\
\hline GBR & & & & & & & - & $5 / 5$ & $5 / 5$ & $5 / 4$ & $3 / 1$ & $4 / 3$ & $4 / 3$ \\
\hline GRC & & & & & & & & - & $4 / 5$ & $4 / 3$ & $3 / 2$ & $3 / 2$ & $4 / 4$ \\
\hline IRE & & & & & & & & & - & $4 / 3$ & $5 / 4$ & $3 / 2$ & $5 / 5$ \\
\hline ITA & & & & & & & & & & - & $3 / 3$ & $2 / 2$ & $4 / 5$ \\
\hline NLD & & & & & & & & & & & - & $3 / 3$ & $4 / 3$ \\
\hline PRT & & & & & & & & & & & & - & $3 / 1$ \\
\hline SWE & & & & & & & & & & & & & - \\
\hline
\end{tabular}

Note: entries indicate cointegrating rank on bilateral system by Johansen Max and Trace test respectively (at $10 \%$ ).

${ }^{6}$ On the contrary, the group $A D F$-statistic indicates cointegration for the bad fiscal performers. 
we do expect this conclusion for the latter group, it is rather surprising for the former.

\section{Assumption 2: Is there international interdependence?}

Comovements across panel units may inadvertently average out the national cointegration relations and therefore invalidate panel tests. In order to test whether countries' fiscal policies co-fluctuate, we repeat for every bilateral pair of countries a cointegration analysis on the fiscal variables of both countries. On this sixvariable system, we apply the Johansen Max and Trace test and simply assume 2 lags. The results for these bi-country systems are reported in Table 8. Only for some countries, there are just two cointegration vectors that can be interpreted as the two national sustainability conditions ${ }^{7}$. But in most cases, there is evidence of a third - and even a fourth - cointegration vector. On closer examination, one of these additional vectors seems to be related to the cross-country correlation of the business cycle, as reflected in government revenues. The other vector seems to relate to comovements in net interest payments, most probably due to some common monetary policy setting in the EU. One way to overcome this international cointegration is to use cyclically adjusted fiscal policy aggregates.

\section{Conclusion}

Now that fiscal rules in the Stability and Growth Pact have been substantially weakened, the no-bailout clause is the central principle guiding fiscal policy making in the EU. Even if governments gained some more flexibility in the short run, national fiscal policies are paradoxally more closely tied together than before via the long-term budget constraints when bailouts are not an implausible scenario anymore. Tests of sustainability on national fiscal policy are less insightful then. Rather, the overall sustainability of public finances in monetary union should be tested. The main contribution of this paper is to test sustainability for a panel of EU countries, exploiting the cointegration between real government revenues, expenditures and net interest payments as a necessary and sufficient condition for the IGBC to hold. The analysis proceeds on two levels. At the national level, sustainability of fiscal policy cannot be accepted for all countries. At the European level, panel cointegration tests indicate European fiscal authorities have maintained sustainable fiscal policies.

${ }^{7}$ Overall, the Trace test statistic somewhat prefers a more parsimonious rank. 
However, the basic assumptions underlying the testing strategy may be violated. First, there is no evidence for a unique order of cointegration for all countries. Second, there are important international links across fiscal policy aggregates. Some solutions have been suggested to overcome this problem.

\section{Acknowledgments}

I would like to thank my supervisors Anindya Banerjee and Michael Artis for helpful suggestions. Comments of an anonymous referee have substantially improved the paper. I also thank participants at the EEFS 2005 Conference for their comments. Any remaining errors are mine. Research is supported under the 'Campilli-Formentini' grant of the European Investment Bank.

Received 5 May 2006, Accepted 31 July 2006

\section{References}

Afonso, A. (2005) Fiscal Sustainability: the unpleasant European Case, FinanzArchiv, 61(1), $19-44$.

Ahmed, S., Rogers, J. (1995) Government Budget Deficits and Trade Deficits. Are Present Value Constraints in Long Term Data?, Journal of Monetary Economics, 36, 351-374.

Arghyrou, M., Luintel, K. (2005) Government Solvency: revisiting some EMU Countries, Journal of Macroeconomics (forthcoming).

Artis, M., Marcellino, M. (1998) Fiscal Solvency and Fiscal Forecasting in Europe, EUI Economics Department working paper 2.

Banerjee A., Marcellino, M., Osbat, C. (2004) Some Cautions on the use of Panel Methods for Integrated Series of Macro-Economic Data, Econometrics Journal, 7, 322-340.

Beetsma, R., Bovenberg, L. (1999) Does Monetary Unification lead to excessive Debt Accumulation?, Journal of Public Economics, 74, 299-325.

Bernoth, K., Von Hagen J., Schuknecht, L. (2004) The Determinants of the Yield Differential in the EU Government Bond Market, CEPR discussion paper 4465.

Bohn, H. (1998) The Behaviour of US Public Debt and Deficits, Quarterly Journal of Economics, 113(3), 949-963.

Bohn, H. (2005) The Sustainability of Fiscal Policy in the United States, CESifo working paper 1446.

Bravo, A., Silvestre, A. (2002) Intertemporal Sustainability of Fiscal Policies: some tests for European countries, European Journal of Political Economy, 18, 517-528. 
Canzoneri, M., Cumby, R. Diba, B. (2001) Is the Price Level determined by the Needs of Fiscal Solvency?, American Economic Review, 91(5), 1221-1238.

Corsetti, G, Roubini, N. (1991) Fiscal Deficits, Public Debt, and Government Solvency: Evidence from OECD Countries, Journal of the Japanese and International Economies, 5, 354-380.

Hakkio, C., Rush, M. (1991) Is the budget deficit too large?, Economic Inquiry, 59, 429445.

Hansen, L., Roberds, W., Sargent, T. (1991) Time Series Implications of Present Value Budget Balance and of Martingale Models of Consumption and Taxes, in Rationa Expectations Econometrics (Ed.) Hansen, L., Sargent, T., Westview Press: Columbia, pp. 121-162.

Haug A. (1990) Cointegration and Government Borrowing Constraints: evidence for the US, Journal of Business and Economics Statistics, 9, 97-101.

IM, K., Pesaran M., Shin, Y. (2003) Testing for Unit Roots in Heterogeneous Panels, Journal of Econometrics, 115, 53-74.

Levin, A., Lin C., Chu, C. (2002) Unit Root Tests in Panel Data: Asymptotic and Finite Sample Properties, Journal of Econometrics, 108, 1-24.

Marinheiro, C.(2006) The Sustainability of Portuguese Fiscal Policy in Historical Perspective, Empirica, 33, 155-179

Pedroni P. (1997) Panel Cointegration: Asymptotic and Finite Sample Properties of pooled Time Series Tests with an Application to PPP, Indiana University working paper 5 .

Pedroni, P. (1999) Critical Values for Cointegration Tests in Heterogeneous Panels with Multiple Regressors, Oxford Bulletin of Economics and Statistics, 61, 653-670.

Trehan B., and Walsh, C. (1991) Testing intertemporal Budget Constraints: Theory and Applications to US Federal Budget and Current Account Deficits, Journal of Money, Credit and Banking, 23, 206-223. 